\title{
Pelatihan Tech for Kids Memperkenalkan STEM untuk Mengembangkan Kemampuan Kepemimpinan Siswa di Era Industri 4.0
}

\author{
Tech for Kids Training Introduces Stems to Develop Student Leadership \\ in the 4.0 Industry Era
}

\author{
Deny Nusyirwan ${ }^{1}$, Eko Prayetno $^{2}$, Sapta Nugraha ${ }^{3}$, Harits Aditya Nugraha $^{4}$, \\ Muhammad Andika ${ }^{5}$, Muhammad Abyan Fadillah ${ }^{6}$ \\ ${ }^{1,2}$ Teknik Perkapalan, ${ }^{3,4,5,6}$ Teknik Elektro \\ Universitas Maritim Raja Ali Haji (UMRAH), Tanjungpinang, Indonesia \\ 1'denynusyirwan@umrah.ac.id, ${ }^{2}$ ekoprayetno@umrah.ac.id, ${ }^{3}$ saptanugraha@umrah.ac.id, \\ 4180120201023@student.umrah.ac.id, 5170120201039@,student.umrah.ac.id, \\ 6180120201022@student.umrah.ac.id
}

Riwayat Artikel: Dikirim 29 September 2020; Diterima 19 November 2020; Diterbitkan 30 November 2020

\begin{abstract}
Abstrak
Industri saat ini sedang mengalami transformasi menuju digitalisasi penuh dan kecerdasan proses manufaktur, yang disebut Revolusi Industri Keempat atau Industri 4.0. Visioner tapi konsep yang cukup realistis seperti aplikasi Internet of Things, Cloud-based Manufacturing dan Smart Manufacturing. Meskipun ada kesepakatan bersama tentang kebutuhan untuk kemajuan teknologi produksi dan model bisnis dalam pengertian Industri 4.0, kendala utama terletak pada persepsi kompleksitas dan keabstrakan yang sebagian menghalangi transformasi cepatnya ke dalam praktik industri. Istilah "pendidikan STEM" mengacu pada pengajaran dan pembelajaran di bidang sains, teknologi, teknik, dan matematika. Biasanya mencakup kegiatan pendidikan di semua tingkat kelas yang dimulai dari masa sebelum masuk sekolah hingga pendidikan tinggi, mulai dari pengaturan secara formal di ruang kelas hingga informal seperti program setelah sekolah. Kepemimpinan siswa berarti siswa mengambil peran aktif dalam pendidikan mereka dan mengembangkan keterampilan positif dalam prosesnya. Tujuan dari pemimpin siswa yang menginspirasi adalah untuk menciptakan budaya kepemilikan dan kolaborasi. Pengembangan kepemimpinan siswa membantu menciptakan keterampilan yang dapat dibawa siswa hingga dewasa. Dengan latar tersebut di lakukan kegiatan pengabdian masyarakat dengan memberikan pelatihan keterampilan STEM untuk menumbuhkan kepemimpinan siswa Madrasah Ibtidaiyah Raudhatul Qur'an Tanjungpinang dalam mempersiapkan diri menghadapi era revolusi industri 4.0. Pelatihan ini dikenal juga dengan Tech for Kids.
\end{abstract}

Kata kunci: keterampilan, kepemimpinan, STEM, kelas, sekolah

\begin{abstract}
The industry is currently undergoing a transformation towards full digitization and intelligence of the manufacturing process, which is called the Fourth Industrial Revolution or Industry 4.0. Visionary but fairly realistic concepts such as Internet of Things, Cloudbased Manufacturing and Smart Manufacturing applications. Although there is mutual agreement on the need for advancement in production technology and business models in the Industry 4.0 sense, the main obstacle lies in the perception of complexity and abstractness which partially hinders its rapid transformation into industrial practice. The term "STEM education" refers to teaching and learning in the fields of science, technology, engineering and mathematics. Usually includes educational activities at all grade levels starting from the period before entering school to higher education, from formal arrangements in the classroom to informal such as after school programs. Student leadership means students take an active role in their education and develop positive skills in the process. The goal of inspiring student leaders is to create a culture of ownership and collaboration. Student leadership development helps create skills that students can carry into adulthood. With this background, community service activities were carried out by providing STEM skills training to foster the leadership of the students of Madrasah Ibtidaiyah Raudhatul Qur'an Tanjungpinang in preparing for the era of the industrial revolution 4.0. This training is also known as Tech for Kids.
\end{abstract}

Keywords: project, scientific, students, industry, smart

Pelatihan Tech for Kids Memperkenalkan STEM untuk Mengembangkan Kemampuan .... 


\section{PENDAHULUAN}

Industri saat ini sedang mengalami transformasi menuju digitalisasi penuh dan kecerdasan proses manufaktur, yang disebut Revolusi Industri Keempat atau Industri 4.0. Visioner tapi konsep yang cukup realistis seperti aplikasi Internet of Things, Cloud-based Manufacturing dan Smart Manufacturing. Meskipun ada kesepakatan bersama tentang kebutuhan untuk kemajuan teknologi produksi dan model bisnis dalam pengertian Industri 4.0, kendala utama terletak pada persepsi kompleksitas dan keabstrakan yang sebagian menghalangi transformasi cepatnya ke dalam praktik industri (Erola, et al.,2016).

Istilah "pendidikan STEM" mengacu pada pengajaran dan pembelajaran di bidang sains, teknologi, teknik, dan matematika. Biasanya mencakup kegiatan pendidikan di semua tingkat kelas yang dimulai dari masa sebelum masuk sekolah hingga pendidikan tinggi, mulai dari pengaturan secara formal di ruang kelas hingga informal seperti program setelah sekolah (Gonzales, dkk., 2014).

Teknologi dan industri mengalami perubahan yang cepat, sistem pendidikan dan pelatihan perlu diarahkan untuk mengembangkan keterampilan untuk memenuhi permintaan pasar. Untuk menghasilkan tenaga kerja Industri 4.0 kompetitif dan bersaing, maka diperlukan keterampilan Sains, Teknologi, Teknik, dan Matematika (STEM) yang kuat. Oleh karena itu, perlu dikembangkan kemampuan STEM yang dibutuhkan di masa depan dengan menyelaraskan kurikulum pendidikan dengan keterampilan yang relevan dengan industri.

Saat ini, pekerjaan di industri yang tumbuh paling cepat didominasi dengan pekerja dengan keterampilan STEM. Untuk menjadi kompetitif, penyedia pekerjaan membutuhkan tenaga kerja yang dapat beradaptasi dengan tempat kerja yang berubah. STEM memberdayakan individu dengan keterampilan untuk sukses dan beradaptasi dengan dunia yang terus berubah tersebut.

Banyak ekonom memprediksi bahwa disrupsi yang berkembang di berbagai industri ditimbulkan oleh percepatan evolusi teknologi pada abad ke21. Kecerdasan buatan, robotika dan otomatisasi, bahan nano, dan adalah merupakan bentuk tsunami yang membawa perubahan pada proses bisnis dengan platform dan jaringan digital. Pada masa depan pekerjaan akan terus berubah. Untuk membantu siswa bertahan dan berkembang dalam lingkungan ketidakpastian tersebut maka perlu mempersiapkan siswa dengan apa yang disebut keterampilan abad ke-21 [3].

Gambar 1.

Keterampilan Abad Ke-21

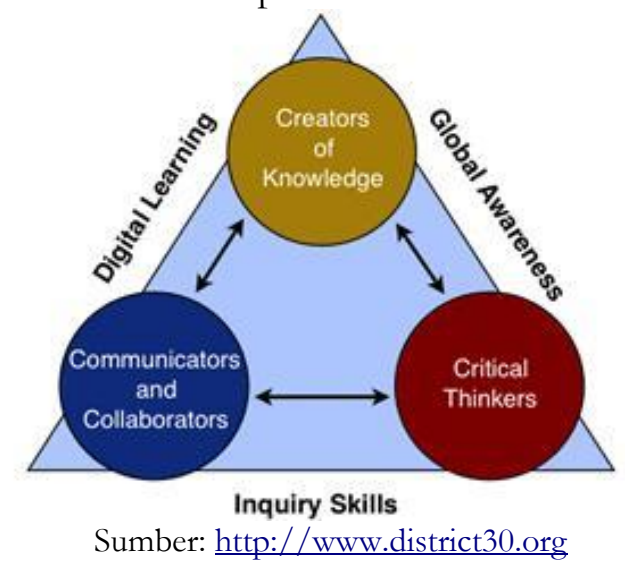

Keterampilan abad ke-21 menitik beratkan pada kemampuan komunikasi (communication) sebagai dasar. Selanjutnya kemampuan bekerja sama (collaboration). Pemikiran kritis (critical thinking) diperlukan ketika menghadapi kompleksitas, ketidakpastian dan memecahkan masalah Selanjutnya kreativitas untuk menghasilkan desain yang berbeda atau inovatif (creator), berupa solusi yang unik atau tidak ada sebelumnya, sila lihat pada Gambar 1. Adap pembelajaran yang mendalam dihasilkan melalui integrasi yang disengaja dari konten akademis yang ketat dengan pengalaman yang secara sengaja menumbuhkan keterampilan, pola pikir, dan literasi yang penting bagi siswa untuk menjadi pembelajar dan kontributor seumur hidup di 
dunia kita yang berubah dengan cepat, sila lihat Gambar 2.

Gambar 2.

Pembelajaran Abad Ke-21

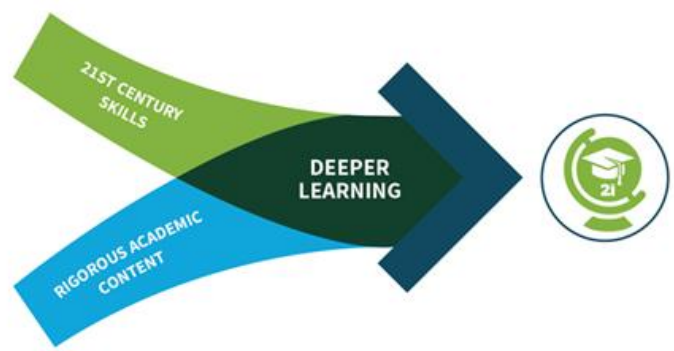

Sumber: https://www.battelleforkids.org

Dunia di sekitar kita terus mengalami sesuatu yang baru setiap hari, berkat gelombang digital yang sangat besar. Anakanak hari ini akan tumbuh dengan gelombang ini dan membawanya ke tingkat berikutnya. Oleh karena itu, penting untuk memberi mereka pengalaman tentang teknologi dalam kehidupan sekolah mereka. Sekolah memiliki tanggung jawab untuk menerapkan teknologi dengan terlebih dahulu memastikan bahwa solusi yang diterapkan mampu mendorong pola pemikiran bagi siswa. Anak-anak lebih mengandalkan intuisi dan lebih sedikit pada informasi. Diperlukan pendekatan yang berbeda untuk memberikan pengetahuan dan pola pikir seorang insinyur kepada siswa. Dengan Tech for Kids, siswa didorong untuk melatih diri dengan keterampilan abad 21, sejalan dengan hal tersebut secara perlahan akan diberikan pengetahuan akademik mengenai teknologi.

\section{METODE}

Anak-anak memiliki kepribadian insinyur secara alami. Dimulai dengan rajin untuk mengotak-atik dan membangun serta membongkar dan menyatukannya kembali. Anak-anak mampu membuat penyesuaian secara cepat dan berimprovisasi tanpa memiliki rasa takut untuk menemukan sesuatu yang baru.

Tidak semua kurikulum STEM dibuat sama, jadi penting bahwa saat mengintegrasikan STEM kepada siswa, dapat disusun sebuah program yang memungkinkan penelitian dan pemecahan masalah di dunia nyata. Salah satu cara untuk melakukannya adalah dengan mencari program STEM yang telah dirancang dengan menggunakan Engineering Design Process (EDP). Proses ini, memberi siswa kesempatan untuk mengembangkan proses pemecahan masalah yang merupakan solusi di dunia nyata. Dengan menguasai EDP, tidak mengatakan bahwa siswa akan tumbuh dan menjadi seorang insinyur, tetapi ada baiknya siswa mempelajari dan memahami apa yang dilakukan oleh seorang insinyur, yaitu proses memecahkan masalah melalui desain.

Gambar 3.

Proses Desain Rekayasa

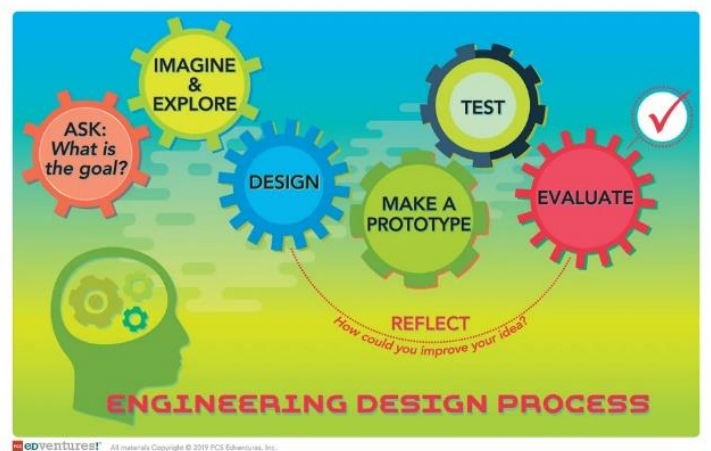

Sumber: https://edventures.com

Pada Gambar 3 menampilkan tahapan-tahapan dari EDP, dimulai dengan identifikasi masalah. Dimulai dengan identifikasi masalah, dilanjutkan dengan curahan gagasan/ide yang dikenal dengan istilah brainstorming. Dalam tahapan ini, siswa akan diajak untuk berpikir secara luas tanpa perlu membatasi diri untuk bisa atau tidak realisasi dari solusi yang diberikan. Luaran dari brainstorming akan di rancang dalam sketsa kertas dan di rakit dalam bentuknya dengan menggunakan bahan-bahan sederhana. Hasil akhir dari solusi terhadap permasalahan di tunjukkan untuk memberikan informasi lengkap mengenai inovasi yang dihasilkan. 


\section{HASIL DAN PEMBAHASAN}

Kegiatan Tech for di Madrasah Ibtidaiyah Swasta (MIS) Raudhatul Qur'an Kids dilaksanakan secara reguler mingguan. Pada Gambar 4. menampilkan lokasi dari sekolah yang bertempat di bagian timur dari Kota Tanjung Pinang. Tanjungpinang. Tanjungpinang adalah sebuah kota yang berlokasi di Pulau Bintan, Provinsi Kepulauan Riau. Lokasinya yang berdekatan dengan negara tetangga Malaysia dan Singapura, mendorong Kota Tanjungpinang untuk wajib memiliki SDM yang mampu menggerakkan ekonomi Provinsi Kepulauan Riau guna berkompetisi secara global.

Gambar 4.

Lokasi Madrasah Ibtidaiyah Raudhatul Qur'an

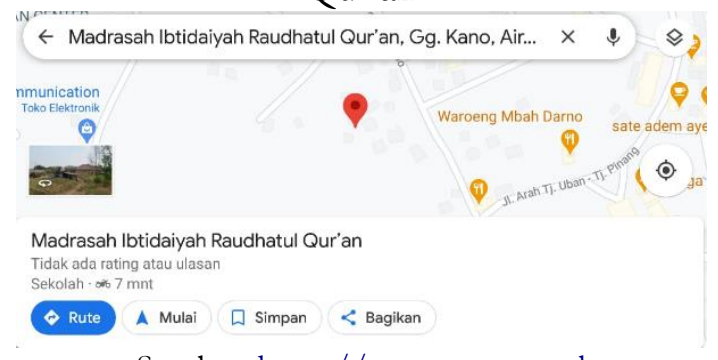

Sumber: https://maps.app.goo.gl

Nama Raudhatul Qur'an diambil dari lokasi sekolah yang berada di tengah masyarakat. Sekolah dilengkapi dengan fasilitas ruang belajar, lapangan olahraga dan masjid. Pelajar yang menghadiri proses belajar mengajar di MI Raudhatul Qur'an pada pagi hari adalah siswa yang menempati Pondok Pesantren Raudhatul Qur'an dan siswa yang bertempat tinggal di luar pondok. Adapun pelatihan TFK ditujukan kepada siswa dan siswi yang bertempat tinggal di dalam Pondok. Pada Gambar 5. menampilkan suasana Madrasah Ibtidaiyah (MI) Raudhatul Qur'an.
Gambar 5.

Madrasah Ibtidaiyah Raudhatul Qur'an
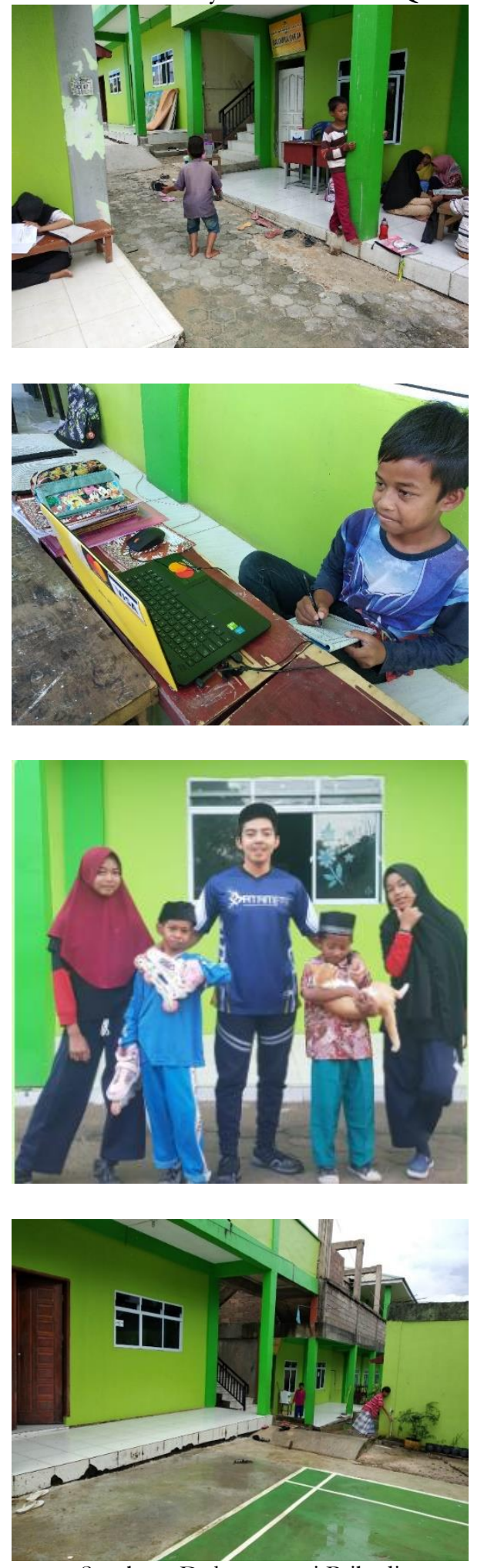

Sumber : Dokumentasi Pribadi 
Pada pertemuan awal, dimulai dengan mengajak siswa untuk memahami pentingnya teknologi didalam kehidupan keseharian dan memperkenalkan TFK. Selanjutnya mengajak siswa untuk memahami secara singkat mengenai tahapan yang diperlukan untuk menghasilkan sebuah solusi dari masalah yang ditemukan, yang dikenal dengan Engineering Design Process (EDP) Pada Tabel 1. menampilkan agenda pelatihan TFK di Madrasah Ibtidaiyah Raudhatul Qur'an Tanjungpinang.

Tabel 1.

Jadwal TFK di Madrasah Ibtidaiyah Raudhatul Qur'an Tanjungpinang

\begin{tabular}{|c|c|c|}
\hline & Bahan Ajar & Pelaksana \\
\hline 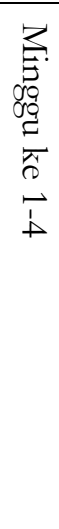 & $\begin{array}{l}\text { 1.Pengenalan Tech } \\
\text { for Kids } \\
\text { 2.Pengenalan } \\
\text { Engineering Design } \\
\text { Process } \\
\text { 3. Observasi } \\
\text { lingkungan } \\
\text { dengan metode } \\
\text { etnografi } \\
\text { 4.Identifikasi } \\
\text { Permasalahan } \\
\text { melalui Etnografi }\end{array}$ & $\begin{array}{l}\text { Dosen } \\
\text { Pendamping, } \\
\text { Mahasiswa } \\
\text { fasilisator } \\
\text { dan siswa/i }\end{array}$ \\
\hline 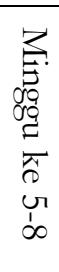 & $\begin{array}{l}\text { 1. Brainstorming } \\
\text { permasalahan } \\
\text { dan menentukan } \\
\text { solusi. } \\
\text { 2. Mensketsa } \\
\text { 3. Virtual Prototyping }\end{array}$ & $\begin{array}{l}\text { Dosen } \\
\text { Pendamping, } \\
\text { Mahasiswa } \\
\text { fasilisator } \\
\text { dan siswa/i }\end{array}$ \\
\hline 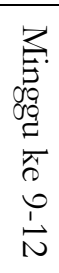 & $\begin{array}{l}\text { Purwarupa } \\
\text { sederhana }\end{array}$ & $\begin{array}{l}\text { Dosen } \\
\text { Pendamping, } \\
\text { Mahasiswa } \\
\text { fasilisator } \\
\text { dan siswa/i }\end{array}$ \\
\hline
\end{tabular}

Pada Gambar 6 memperlihatkan dosen pendamping sedang memberikan pengantar mengenai TFK di dalam kelas kepada siswa.. Mahasiswa yang merupakan fasilitator pelatihan secara aktif mendampingi siswa untuk memahami informasi yang disampaikan oleh dosen pendamping.

Gambar 6.

Suasana Pembelajaran Pada Pertemuan Pertama

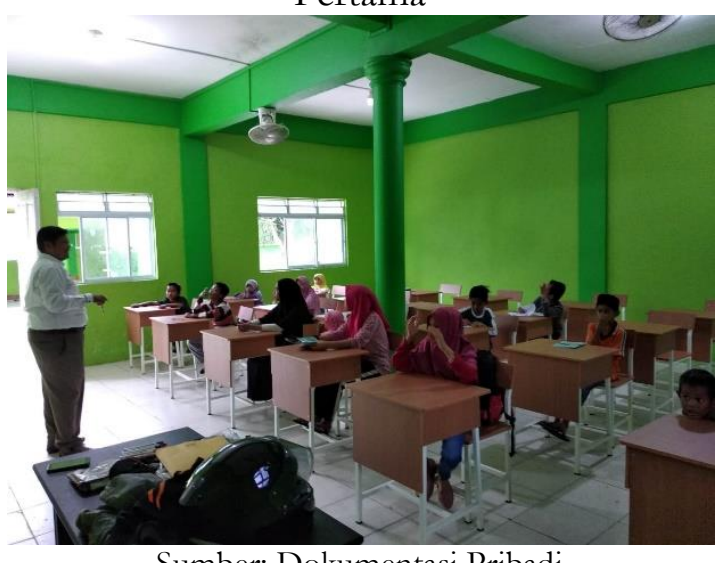

Sumber: Dokumentasi Pribadi

Adapun nama mahasiswa yang menjadi fasilitator dalam pelatihan dan siswa yang terlibat dalam pelatihan Tech for Kids dapat dilihat pada Tabel 2.

Tabel 2.

Data Peserta dan Fasilitator Pendamping Tech for Kids Tahun 2020

\begin{tabular}{|c|c|c|c|}
\hline $\begin{array}{l}\text { Nama } \\
\text { Sekolah }\end{array}$ & $\begin{array}{l}\text { Dosen } \\
\text { Pembim- } \\
\text { bing }\end{array}$ & Siswa & $\begin{array}{c}\text { Fasilisator } \\
\text { pendam- } \\
\text { ping }\end{array}$ \\
\hline $\begin{array}{l}\text { Madrasah } \\
\text { Ibtidaiyah } \\
\text { Raudhatul } \\
\text { Qur'an }\end{array}$ & $\begin{array}{l}\text { 1. Deny } \\
\text { Nusyirwan, } \\
\text { S.T., M.Sc. } \\
\text { 2. Eko } \\
\text { Prayetno, } \\
\text { S.T., } \\
\text { M.Eng } \\
\text { 3. Sapta } \\
\text { Nugraha, } \\
\text { S.T., } \\
\text { M.Eng } \\
\text { 4. Anton } \\
\text { Hekso } \\
\text { Yunianto, } \\
\text { S.T., M.Si } \\
\text { 5. Tonny } \\
\text { Suhendra, } \\
\text { S.T., M.Cs. }\end{array}$ & $\begin{array}{l}\text { 1. Aril } \\
\text { Ramadhan } \\
\text { 2. Sahdana } \\
\text { Fauzi Latif } \\
\text { 3. Dani } \\
\text { Meldani } \\
\text { Warta } \\
\text { 4. Kevin } \\
\text { Wijaya } \\
\text { Kusuma } \\
\text { 5. Muhammad } \\
\text { Ridwan } \\
\text { 6. Ahsanul } \\
\text { Khaliq } \\
\text { Yunus } \\
\text { 7. Ahsin } \\
\text { Yunus } \\
\text { 8. Muhammad } \\
\text { Hafizul } \\
\text { Ahkam } \\
\text { 9. Hidayat } \\
\text { Pangestu } \\
\text { 10. Charly } \\
\text { Muhammad } \\
\text { Nazrul }\end{array}$ & $\begin{array}{l}\text { 1. Harits } \\
\text { Aditya } \\
\text { Nugraha } \\
\text { 2. M. } \\
\text { Andika } \\
\text { 3. M. } \\
\text { Abyan } \\
\text { Fadillah }\end{array}$ \\
\hline
\end{tabular}




\begin{tabular}{|c|c|c|c|}
\hline $\begin{array}{c}\text { Nama } \\
\text { Sekolah }\end{array}$ & $\begin{array}{c}\text { Dosen } \\
\text { Pembim- } \\
\text { bing }\end{array}$ & Siswa & $\begin{array}{c}\text { Fasilisator } \\
\text { pendam- } \\
\text { ping }\end{array}$ \\
\hline & & 11.Sahdina & \\
& & Fauzia & \\
& & Herlan & \\
& & 12.Putri Yarni & \\
& & Tari & \\
& & 13. Kesya & \\
& & Septia & \\
& & Aliska & \\
& & 14. Aulia & \\
& & Alawia Zen & \\
& & 15. Kanaya & \\
& & Amelia & \\
& & Putri & \\
& & 16. Liren & \\
& & Aprilia & \\
& & Larensa & \\
& & 17. Sanisa & \\
& & Mutiara & \\
& & Koto & \\
& & & \\
& & &
\end{tabular}

Dalam tahapan identifikasi permasalahan melalui etnografi dan brainstorming, siswa diberikan pemahaman mengenai permasalahan-permasalahan yang ditemukan di sekitar sekolah melalui metode etnografi. Etnografi sudah dikenal luas tidak hanya oleh kalangan antropologi namun juga oleh perusahaan yang bergerak di bidang inovasi. Dengan memanfaatkan metode etnografi, maka informasi yang dikumpulkan akan lebih akurat. Etnografi berasal dari kata etno dan grafi, yang berarti etnik dan daerah. Proses Etnografi adalah proses mempelajari pola hidup masyarakat di suatu daerah melalui pendekatan secara sosial. Pada Gambar 7 menunjukkan mahasiswa sebagai fasilitator pelatihan Tech for Kids mendampingi siswa untuk mengenal etnografi

Di dalam proses brainstorming, setiap pendapat dapat diterima. Proses yang dikenal juga dengan sebutan proses divergent. Curahan gagasan merupakan bagian penting seorang rekayasawan untuk mampu menghasilkan inovasi yang bermanfaat secara luas di sekolah nantinya. Sila lihat Gambar 8.
Gambar 7.
Mahasiswa Berintegrasi Langsung Dengan Siswa

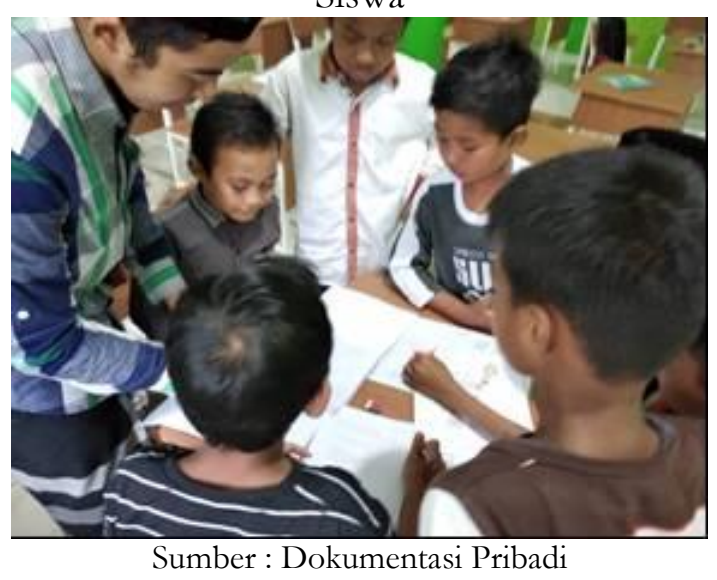

Gambar 8.

Siswa Dan Siswi Melakukan Curahan Gagasan

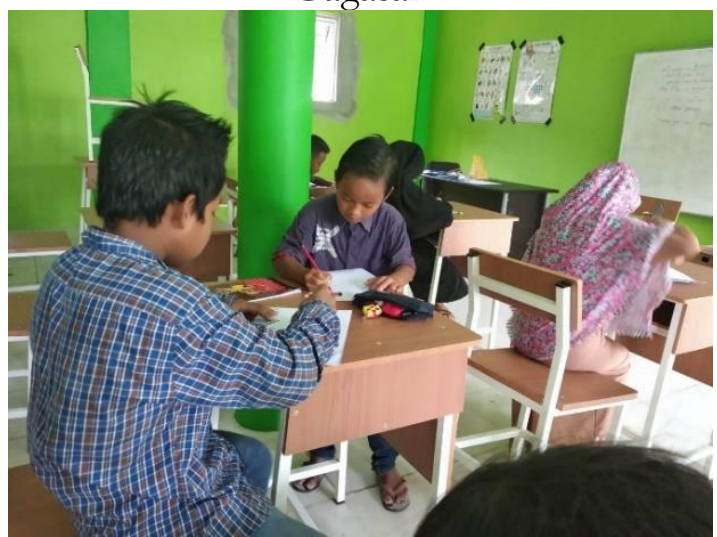

Sumber : Dokumentasi Pribadi

Pemecahan masalah sangat penting untuk menghasilkan inovasi. Insinyur terus mencari cara yang lebih baik untuk melakukan sesuatu. Pada tahap ini, desainer harus memiliki dasar yang kuat dan memahami masalah yang dihadapi, memiliki serangkaian tujuan yang ingin difokuskan dan yang paling penting adalah harus memiliki beberapa solusi kreatif. Perhatikan dengan cermat informasi yang telah dimiliki sejauh ini. Sederhanakan, dan hapus apa pun yang membebani inovasi untuk dapat dicapai melalui cara yang lebih sederhana. Gambar 9 menampilkan siswa menyampaikan masalah dan solusi utama. 
Gambar 9.

Proses Curahan Gagasan Untuk

Mendorong Siswa Menyamapaikan

Permasalahan Utama Dan Meberikan

Solusi Utama Secara Bebas

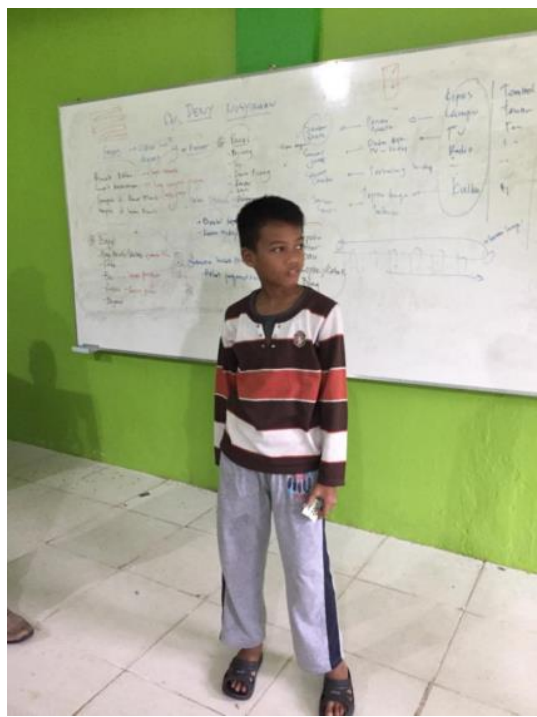

Sumber : Dokumentasi Pribadi

Gambar 10.

Pembuatan Purwarupa Virtual

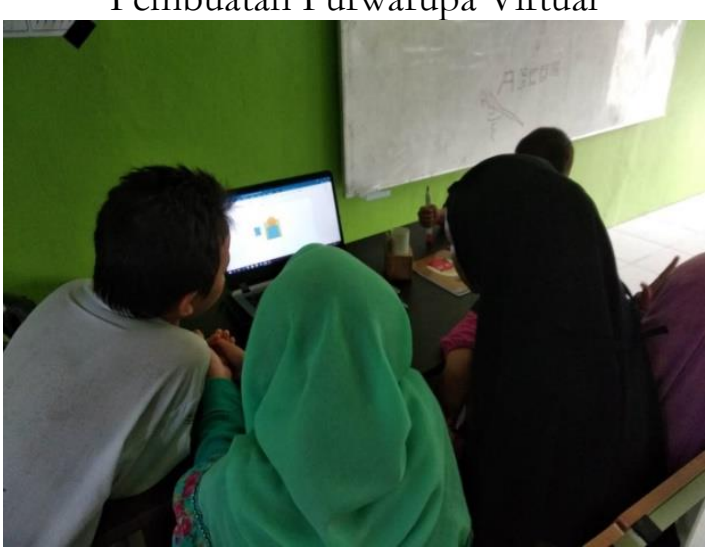

Sumber : Dokumentasi Pribadi

Seringkali, bentuk sketsa yang digambar dengan tangan memiliki informasi yang belum sempurna, purwarupa pada tahap ini tidak memiliki fungsi yang dapat dibuktikan. Sketsa terebut hanyalah representasi ide yang ditulis atau digambar. Sebuah bukti terhadap sebuah konsep inovasi hanya dapat dipahami sebaik cara desainer menjelaskannya. Informasi terlampir tentang dimensi, bahan, bentuk, perakitan, dan fitur menentukan apakah desainer memiliki ide yang valid. Oleh sebab itu, desainer menggunakan purwarupa virtual untuk memungkinkan mengeksplorasi dan memvalidasi ide sebelum menginvestasikan terlalu banyak sumber daya dalam membangun produk yang sebenarnya (Elverum, dkk.,2018). Pada Gambar 10 dapat dilihat siswa secara aktif melatih diri untuk menggunakan komputer guna mempelajari pembuatan purwarupa virtual.

Tahapan pembuatan purwarupa fisik sederhana adalah merupakan tahapan dari Proses Desain Rekayasa yang sudah mulai memerlukan pembiayaan. Adapun Purwarupa fisik dan visual memiliki tujuan yang sama namun dengan cara pencapaian yang berbeda (Gibson, dkk.,2004). Pada tahapan ini, perancang akan memulai pembuatan purwarupa yang ekonomis dan fleksibel, dengan maksud bahwa perubahan rancangan dapat dilakukan dengan mudah dan tidak akan memerlukan pembiayaan yang besar. Penentuan jenis purwarupa yang akan dipergunakan ditentukan dengan mempertimbangkan waktu, biaya dan pengalaman dari setiap siswa. Pada Gambar 11 menampilkan aktivitas siswa di dalam merakit purwarupa fisik dari bahan-bahan ekonomis dan sederhana.

Gambar 11.

Perakitan Purwarupa Fisik Sederhana Dan Ekonomis

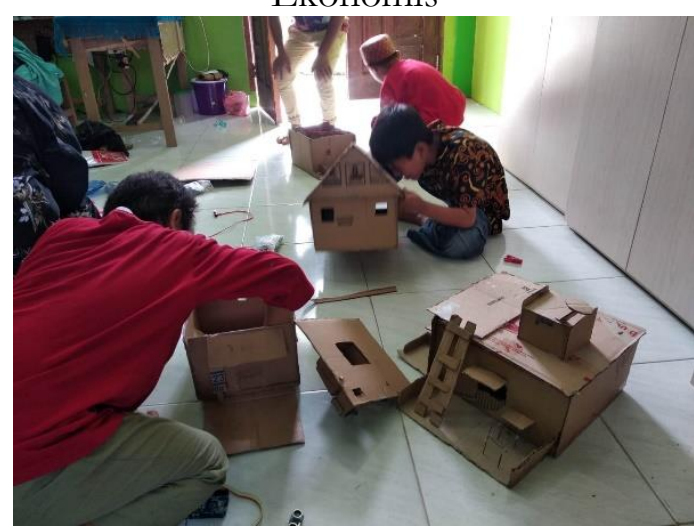

Sumber : Dokumentasi Pribadi 


\section{KESIMPULAN}

Berpikir secara mendalam tentang mata pelajaran adalah bagian penting dari pembelajaran. Pendidik selalu ingin siswanya berpikir tentang apa yang diajarkan, tetapi cara mereka mendorong proses itu berubah. Guru tidak lagi memberi tahu siswa apa yang harus dipikirkan. Sebaliknya, mereka mengajari mereka cara berpikir. Instruktur saat ini berusaha membangun kepemimpinan siswa melalui teknik pengajaran mereka. Pemimpin kelompok siswa kemudian menjadi pemikir independen yang memahami cara bekerja sebagai bagian dari tim dan memiliki efek positif .

Kepemimpinan siswa berarti siswa mengambil peran aktif dalam pendidikan mereka dan mengembangkan keterampilan positif dalam prosesnya. Tujuan dari pemimpin siswa yang menginspirasi adalah untuk menciptakan budaya kepemilikan dan kolaborasi. Pengembangan kepemimpinan siswa membantu menciptakan keterampilan yang dapat dibawa siswa hingga dewasa.

Dengan latar tersebut di lakukan kegiatan pengabdian masyarakat dengan memberikan pelatihan keterampilan STEM untuk menumbuhkan kepemimpinan siswa Madrasah Ibtidaiyah Raudhatul Qur'an Tanjungpinang dalam mempersiapkan diri menghadapi era revolusi industri 4.0. Pelatihan ini dikenal juga dengan Tech for Kids.

Tabel 3. menampilkan hasil Pelatihan Tech for Kids di MIS Raudhatul Qur'an Tanjungpinang Timur terkait kepemimpinan dan tanggung jawab, yaitu memandu dan memimpin orang lain.
Tabel 3.

Parameter yang Dipergunakan Untuk Mengukur Hasil Pelatihan

\begin{tabular}{|c|c|c|c|c|}
\hline \multicolumn{5}{|c|}{$\begin{array}{c}\text { KEPEMIMPINAN DAN } \\
\text { TANGGUNG JAWAB }\end{array}$} \\
\hline \multicolumn{5}{|c|}{$\begin{array}{c}\text { Memandu dan Memimpin } \\
\text { Orang Lain }\end{array}$} \\
\hline & $\begin{array}{c}4 \\
\text { Sangat } \\
\text { Baik }\end{array}$ & $\begin{array}{c}3 \\
\text { Baik }\end{array}$ & $\begin{array}{c}2 \\
\text { Cukup }\end{array}$ & $\begin{array}{c}1 \\
\text { Kurang }\end{array}$ \\
\hline $\begin{array}{l}\text { Menggu } \\
\text { nakan } \\
\text { keteram } \\
\text { pilan } \\
\text { interpers } \\
\text { onal dan } \\
\text { pemecah } \\
\text { an } \\
\text { masalah } \\
\text { untuk } \\
\text { mempen } \\
\text { garuhi } \\
\text { dan } \\
\text { membim } \\
\text { bing } \\
\text { orang } \\
\text { lain } \\
\text { menuju } \\
\text { tujuan }\end{array}$ & $\begin{array}{l}\text { Efektif } \\
\text { berkomu } \\
\text { nikasi dan } \\
\text { termotiva } \\
\text { si es lain t } \\
\text { o } \\
\text { memecah } \\
\text { kan } \\
\text { masalah } \\
\text { kelompok } \\
\text { sementara } \\
\text { mencapai } \\
\text { tujuan }\end{array}$ & $\begin{array}{l}\text { Secara } \\
\text { efektif } \\
\text { mengk } \\
\text { omunik } \\
\text { asikan } \\
\text { dan } \\
\text { memoti } \\
\text { vasi } \\
\text { orang } \\
\text { lain } \\
\text { untuk } \\
\text { bekerja } \\
\text { menuju } \\
\text { tujuan }\end{array}$ & $\begin{array}{l}\text { Berusaha } \\
\text { untuk } \\
\text { bekerja } \\
\text { dengan } \\
\text { orang lain } \\
\text { untuk } \\
\text { mencapai } \\
\text { tujuan, } \\
\text { tetapi } \\
\text { gagal } \\
\text { berkomu } \\
\text { nikasi } \\
\text { secara } \\
\text { efektif } \\
\text { untuk } \\
\text { memecah } \\
\text { kan } \\
\text { masalah } \\
\text { atau } \\
\text { memotiva } \\
\text { si orang } \\
\text { lain }\end{array}$ & $\begin{array}{l}\text { Menunjuk } \\
\text { kan tidak } \\
\text { ada tanda } \\
\text { minat } \\
\text { dalam } \\
\text { mencapai } \\
\text { suatu } \\
\text { tujuan }\end{array}$ \\
\hline $\begin{array}{l}\text { Memanf } \\
\text { aatkan } \\
\text { kekuatan } \\
\text { orang } \\
\text { lain } \\
\text { untuk } \\
\text { mencapa } \\
\text { i tujuan } \\
\text { bersama }\end{array}$ & $\begin{array}{l}\text { Secara } \\
\text { konsisten } \\
\text { mendoro } \\
\text { ng dan } \\
\text { memotiva } \\
\text { si orang } \\
\text { lain untuk } \\
\text { menggun } \\
\text { akan } \\
\text { kekuatan } \\
\text { mereka } \\
\text { untuk } \\
\text { berkontri } \\
\text { busi dan } \\
\text { mencapai } \\
\text { tujuan } \\
\text { bersama. }\end{array}$ & $\begin{array}{l}\text { Mendo } \\
\text { rong } \\
\text { orang } \\
\text { lain } \\
\text { untuk } \\
\text { mengg } \\
\text { unakan } \\
\text { kekuata } \\
\mathrm{n} \\
\text { mereka } \\
\text { untuk } \\
\text { berkont } \\
\text { ribusi } \\
\text { dan } \\
\text { mencap } \\
\text { ai } \\
\text { tujuan } \\
\text { bersam } \\
\text { a. }\end{array}$ & $\begin{array}{l}\text { Tunjukka } \\
\mathrm{n} \\
\text { dorongan } \\
\text { terbatas } \\
\text { kepada } \\
\text { orang lain } \\
\text { untuk } \\
\text { mencapai } \\
\text { tujuan } \\
\text { bersama. }\end{array}$ & $\begin{array}{l}\text { Negatif } \\
\text { terhadap } \\
\text { orang lain } \\
\text { dalam } \\
\text { mencapai } \\
\text { tujuan } \\
\text { bersama. }\end{array}$ \\
\hline $\begin{array}{l}\text { Mengins } \\
\text { pirasi } \\
\text { orang } \\
\text { lain } \\
\text { untuk } \\
\text { mencapa } \\
\text { i yang } \\
\text { terbaik } \\
\text { melalui } \\
\text { teladan } \\
\text { dan } \\
\text { tidak } \\
\text { mementi } \\
\text { ngkan } \\
\text { diri } \\
\text { sendiri }\end{array}$ & $\begin{array}{l}\text { Menyisih } \\
\text { kan } \\
\text { kebutuha } \\
\text { n pribadi } \\
\text { dan } \\
\text { mengilha } \\
\text { mi orang } \\
\text { lain untuk } \\
\text { tampil } \\
\text { dengan } \\
\text { kemampu } \\
\text { an terbaik } \\
\text { mereka } \\
\text { terlepas } \\
\text { dari } \\
\text { rintangan } \\
\text { atau }\end{array}$ & $\begin{array}{l}\text { Membe } \\
\text { rikan } \\
\text { inspiras } \\
\text { i } \\
\text { dengan } \\
\text { menunj } \\
\text { ukkan } \\
\text { kepada } \\
\text { orang } \\
\text { lain } \\
\text { untuk } \\
\text { tampil } \\
\text { pada } \\
\text { kemam } \\
\text { puan } \\
\text { terbaik } \\
\text { mereka }\end{array}$ & $\begin{array}{l}\text { Terkadan } \\
\mathrm{g} \\
\text { menginsp } \\
\text { irasi } \\
\text { orang lain } \\
\text { untuk } \\
\text { tampil } \\
\text { pada } \\
\text { kemampu } \\
\text { an terbaik } \\
\text { mereka } \\
\text { tetapi } \\
\text { kadang- } \\
\text { kadang } \\
\text { memungk } \\
\text { inkan } \\
\text { kebutuha }\end{array}$ & $\begin{array}{l}\text { Gagal } \\
\text { menginsp } \\
\text { irasi } \\
\text { orang } \\
\text { lain. }\end{array}$ \\
\hline
\end{tabular}




\begin{tabular}{|c|c|c|c|c|}
\hline \multicolumn{5}{|c|}{$\begin{array}{c}\text { KEPEMIMPINAN DAN } \\
\text { TANGGUNG JAWAB }\end{array}$} \\
\hline \multicolumn{5}{|c|}{$\begin{array}{c}\text { Memandu dan Memimpin } \\
\text { Orang Lain }\end{array}$} \\
\hline & $\begin{array}{c}4 \\
\text { Sangat } \\
\text { Baik }\end{array}$ & $\begin{array}{c}3 \\
\text { Baik }\end{array}$ & $\begin{array}{c}2 \\
\text { Cukup }\end{array}$ & $\begin{array}{c}1 \\
\text { Kurang }\end{array}$ \\
\hline & $\begin{array}{l}\text { memperti } \\
\text { mbangka } \\
\mathrm{n} \\
\text { keberhasil } \\
\text { an } \\
\text { mereka } \\
\text { sendiri. }\end{array}$ & $\begin{array}{l}\text { terlepas } \\
\text { dari } \\
\text { rintang } \\
\text { an di } \\
\text { hadapa } \\
\text { n } \\
\text { mereka. }\end{array}$ & $\begin{array}{l}\mathrm{n} \text { egois } \\
\text { untuk } \\
\text { mengamb } \\
\text { il } \\
\text { preseden. }\end{array}$ & \\
\hline $\begin{array}{l}\text { Menunju } \\
\text { kkan } \\
\text { integrita } \\
\text { s dan } \\
\text { perilaku } \\
\text { etis } \\
\text { dalam } \\
\text { menggu } \\
\text { nakan } \\
\text { pengaru } \\
\text { h dan } \\
\text { kekuatan }\end{array}$ & $\begin{array}{l}\text { Ketika } \\
\text { berada } \\
\text { dalam } \\
\text { posisi } \\
\text { kekuasaan } \\
\text { berperilak } \\
\text { u secara } \\
\text { etis dan } \\
\text { dengan } \\
\text { integritas } \\
\text { untuk } \\
\text { memotiva } \\
\text { si orang } \\
\text { lain agar } \\
\text { bekerja } \\
\text { dengan } \\
\text { potensi } \\
\text { penuh } \\
\text { mereka }\end{array}$ & $\begin{array}{l}\text { Tidak } \\
\text { menyal } \\
\text { ahguna } \\
\text { kan } \\
\text { posisi } \\
\text { kepemi } \\
\text { mpinan } \\
\text { mereka } \\
\text { untuk } \\
\text { mengu } \\
\text { ntungk } \\
\text { an diri } \\
\text { sendiri } \\
\text { dengan } \\
\text { bersika } \\
\text { p etis } \\
\text { dan } \\
\text { menunj } \\
\text { ukkan } \\
\text { integrit } \\
\text { as }\end{array}$ & $\begin{array}{l}\text { Kadang- } \\
\text { kadang } \\
\text { menempa } \\
\text { tkan } \\
\text { kebutuha } \\
\text { n pribadi } \\
\text { dan tidak } \\
\text { menerapk } \\
\text { an etika } \\
\text { dan } \\
\text { integritas } \\
\text { pada } \\
\text { keputusan } \\
\text { atau } \\
\text { tindakan } \\
\text { mereka. }\end{array}$ & $\begin{array}{l}\text { Ketika } \\
\text { dalam } \\
\text { posisi } \\
\text { kekuasaan } \\
\text {, s } \\
\text { bagaiman } \\
\text { a s tidak } \\
\text { ada } \\
\text { tanda- } \\
\text { tanda } \\
\text { integritas } \\
\text { atau } \\
\text { perilaku } \\
\text { etis }\end{array}$ \\
\hline
\end{tabular}

Gambar 12 menampilkan kondisi pada penilaian awal siswa, dan Gambar 13. merupakan hasil Pelatihan Tech for Kids di MIS Raudhatul Qur'an Tanjungpinang Timur

Gambar 12.

Kondisi Pada Penilaian Awal Siswa
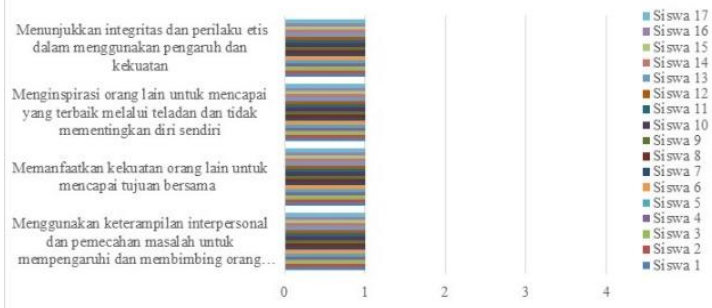

Sumber : Dokumentasi Pribadi
Gambar 13.

Hasil Pelatihan Tech for Kids di MIS

Raudhatul Qur'an Tanjungpinang Timur

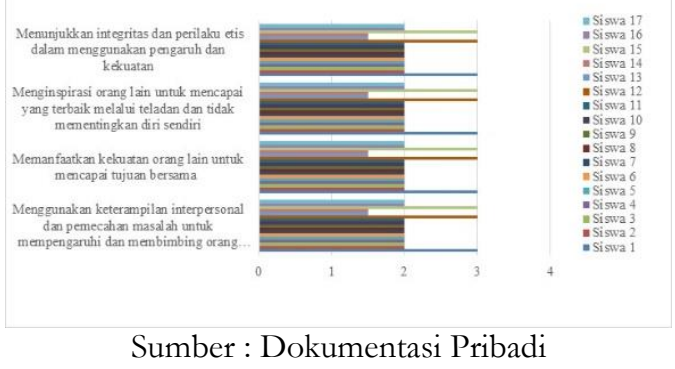

\section{UCAPAN TERIMA KASIH}

Ucapan terima kasih kami sampaikan terutama kepada Lembaga Penelitian, Pengabdian Masyarakat dan Penjaminan Mutu (LP3M), Universitas Maritim Raja Ali Haji sesuai dengan perjanjian pendanaan pelaksanaan program Pengabdian Kepada Masyarakat Nomor: 053/UN53.02/Kontrak-PKM/I/2020, 01 April 2020. Selain itu, juga disampaikan terima kasih kepada mahasiswa dan dosen yang terlibat di jurusan teknik perkapalan dan elektro UMRAH serta Sekolah Madrasah Ibtidaiyah Raudhatul Qur'an di Tanjungpinang Timur

\section{DAFTAR PUSTAKA}

Erola, S., Jägera, A., Holda, P., Otta, K., \& Sihna, W. (2016). Tangible Industry 4.0: a scenario-based approach to learning for the future of production ,6th CLF - 6th CIRP Conference on Learning Factories,

Gonzalez, H. B., \& Kuenzi, J. J. (2014). Science, technology, engineering, and mathematics (STEM) education: A primer

Reaves, J. (2019). 21st-Century Skills And The Fourth Industrial Revolution: A Critical Future Role For Online Education, International Journal on Innovations in Online Education, 3 (1)

$21^{\text {st }}$ Century Learning. Retrieved September 29, 2020, from http://www.district30.org/academics/21stcentury-learning/ 
The Journey to 21st Century Learning for All Students. Retrieved September 29, 2020, from

https://www.battelleforkids.org/learninghub/learning-hub-item/the-journey-to-21stcentury-learning-for-all-students

Engineering Design Process. Retrieved September 29, 2020, from https://edventures.com/blogs/stempower/i ntegrating-the-engineering-design-processin-stem-spaces

Madrasah Ibtidaiyah Raudhatul Qur'an, Gg. Kano, Air Raja, Kec. Tanjungpinang Tim., Kota Tanjung Pinang, Kepulauan Riau 29125. Retrieved September 29, 2020, from https://maps.app.goo.gl/1FyEQSRZQ6pjS cjT9

Elverum, C. W., Welo, T., \& Tronvoll, S. (2016). Prototyping in New Product Development:

Considerations.

Gibson, I., Gao, Z., \& Campbell, R. I. (2004). A comparative study of virtual prototyping and physical prototyping, International Journal of Manufacturing Technology and Management. 6: 503-522 